\title{
Selective Leaching and Surface Properties of Cu-Al-Ni Shape Memory Alloys
}

\author{
Shih-Hang Chang*1, Chin Kuo*2 and Jin-Lin Han \\ Department of Chemical and Materials Engineering, National I-Lan University, I-Lan 260, Taiwan
}

This study investigated the selective leaching, chemical compositions, and electrochemical properties of $\mathrm{Cu}-\mathrm{XAl}-4 \mathrm{Ni}(\mathrm{X}=12.5,13.0$, and 13.5) shape memory alloys (SMAs). The selective leaching results showed that the $\mathrm{Cu}-\mathrm{XAl}-4 \mathrm{Ni}$ SMAs released approximately $200 \mathrm{ppb}$ of $\mathrm{Cu}$ ions, $200 \mathrm{ppb}$ of $\mathrm{Al}$ ions, and $600 \mathrm{ppb}$ of $\mathrm{Ni}$ ions after immersion in Ringer's solution for 90 days. The low concentrations of $\mathrm{Cu}$ and $\mathrm{Al}$ ions stem from the oxidation of $\mathrm{Cu}$ and $\mathrm{Al}$ atoms near the surface of the $\mathrm{Cu}-\mathrm{XAl}-4 \mathrm{Ni}$ SMAs to form $\mathrm{Cu}_{2} \mathrm{O}$ and $\mathrm{Al}_{2} \mathrm{O}_{3}$ films. The selective leaching properties of the $\mathrm{Cu}-\mathrm{XAl}-4 \mathrm{Ni}$ SMAs were inferior to that of the TiNi SMA, which possessed a highly passive $\mathrm{TiO}_{2}$ film on the surface, but were much better than those of the TiNiCu and TiNiFe SMAs, whose $\mathrm{TiO}_{2}$ films were deteriorated by the formation of $\mathrm{NiO}, \mathrm{Cu}_{2} \mathrm{O}$, and $\mathrm{Fe}_{2} \mathrm{O}_{3}$ oxides. $\mathrm{Cu}-\mathrm{XAl}-4 \mathrm{Ni}$ SMAs are potential candidates to serve as biomaterials, owing to their acceptable surface and selective leaching properties, high martensitic transformation temperatures, low cost, good machinability, and excellent electric and thermal conductivities. [doi:10.2320/matertrans.M2017287]

(Received September 21, 2017; Accepted February 15, 2018; Published April 25, 2018)

Keywords: $\mathrm{Cu}-\mathrm{Al}-\mathrm{Ni}$ shape memory alloys, biomaterials, selective leaching, X-ray photoelectron spectroscopy

\section{Introduction}

Nickel-titanium shape memory alloys (TiNi SMAs) have been widely investigated owing to their unique shape memory effect, superelasticity, and good damping capacity. ${ }^{1)}$ TiNi SMAs typically exhibit low cytotoxicity and low genotoxicity, ${ }^{2-4)}$ and therefore are suitable for biomedical applications such as laparoscopic surgery, intracoronary stents, ligament replacement, endodontic instruments, and osteosynthesis devices. ${ }^{5-8)}$ However, long-term interactions between TiNi SMAs and living tissues may cause the release of nickel ions, ${ }^{9)}$ which may induce undesirable allergy or cancer. ${ }^{10,11)}$ The selective leaching characteristics of TiNibased SMAs have been widely investigated. ${ }^{12-19)}$ Chu et al. ${ }^{12-14)}$ reported that the surface properties of TiNi SMAs oxidized using boiling $\mathrm{H}_{2} \mathrm{O}_{2}$ solution and a $\mathrm{UV} / \mathrm{H}_{2} \mathrm{O}_{2}$ photocatalytic system could notably suppress $\mathrm{Ni}$ ion release and improve the biocompatibility of the alloys. Gil et al. ${ }^{15-17)}$ studied the Ni release behaviors of TiNi orthodontic archwires and reported that the titanium oxide on their surface significantly improves the corrosion resistance and decreases the $\mathrm{Ni}$ ion release of the alloys. Chang et al. ${ }^{18,19)}$ reported that $\mathrm{TiNiCu}$ and TiNiFe SMAs exhibited higher selective leaching rates of $\mathrm{Ni}$ ions compared to that of TiNi SMA.

Compared with TiNi SMAs, $\mathrm{Cu}-\mathrm{Al}-\mathrm{Ni}$ SMAs also exhibit a good shape memory effect, superelasticity and damping capacity, but possess the advantages of lower cost, better workability, superior thermal and electrical conductivities, and more easily obtainable desirable martensitic transformation temperatures by adjustment of the chemical composition of the alloys. ${ }^{20-27)}$ Nevertheless, only a few studies have investigated the feasibility of biomedical applications of $\mathrm{Cu}-\mathrm{Al}-\mathrm{Ni}$ SMAs. Čolić et al. ${ }^{28-30)}$ reported via an in vitro investigation that rapidly solidified $\mathrm{Cu}-\mathrm{Al}-\mathrm{Ni}$ SMA ribbons possessed good corrosion resistance, cytotoxicity, and biocompatibility. Chang et al. ${ }^{31)}$ investigated the toxicity of $\mathrm{Cu}-\mathrm{Al}-\mathrm{Ni}$ SMAs for Escherichia coli using a probit dose-response model and augmented

\footnotetext{
${ }^{* 1}$ Corresponding author, E-mail: shchang@niu.edu.tw

${ }^{* 2}$ Graduate Student, National I-Lan University
}

simplex design. According to their study, high concentrations of $\mathrm{Al}$ and $\mathrm{Ni}$ ions inhibited the growth of Escherichia coli; however, the toxicity of $\mathrm{Cu}$ ion was found to be chronic, rather than acute. Moreover, the surface properties and the selective leaching behaviors of $\mathrm{Cu}-\mathrm{Al}-\mathrm{Ni}$ SMAs have not been studied in detail. Therefore, the aim of this study is to investigate the surface properties and concentrations of the $\mathrm{Cu}, \mathrm{Al}$, and $\mathrm{Ni}$ ions released from $\mathrm{Cu}-\mathrm{XAl}-4 \mathrm{Ni}(\mathrm{X}=12.5$, 13.0, and 13.5) SMAs immersed in Ringer's solution. Ringer's solution was used in this study because it is an isotonic solution similar to bodily fluid, which is widely used in in vitro experiments. $\mathrm{Cu}-\mathrm{XAl}-4 \mathrm{Ni}(\mathrm{X}=12.5,13.0$, and 13.5) SMAs were selected for this study because they typically exhibit a more significant $\beta_{1} \leftrightarrow \beta_{1}^{\prime}$ martensitic transformation at a higher temperature than the $\beta_{1} \leftrightarrow \gamma_{1}^{\prime}$ martensitic transformation of $\mathrm{Cu}-\mathrm{XAl}-4 \mathrm{Ni}$ SMAs with $\mathrm{X}>14.0{ }^{24)}$ Moreover, $\gamma_{2}$ phase typically precipitated on the surface of $\mathrm{Cu}-\mathrm{XAl}-4 \mathrm{Ni}$ SMAs with $\mathrm{X}>14.0$, which may deteriorate the surface property of the alloys. ${ }^{23,24,32)}$

\section{Experimental Procedures}

The $\mathrm{Cu}-\mathrm{XAl}-4 \mathrm{Ni}(\mathrm{X}=12.5,13.0$, and 13.5) SMAs were prepared from pure raw materials of copper (purity 99.9 wt.\%), aluminum (purity $99.99 \mathrm{wt} . \%$ ), and nickel (purity $99.9 \mathrm{wt} . \%$ ). The raw materials were melted at $1100^{\circ} \mathrm{C}$ in evacuated quartz followed by quenching in ice water. The quenched ingots were annealed at $900^{\circ} \mathrm{C}$ for $30 \mathrm{~min}$ and then cooled in the furnace to room temperature. The crystallographic features of the $\mathrm{Cu}-\mathrm{XAl}-4 \mathrm{Ni}$ SMAs were determined using a Rigaku IV X-ray diffraction (XRD) instrument with $\mathrm{Cu} \mathrm{K} \alpha$ radiation $(\lambda=0.154 \mathrm{~nm})$. Microstructural observations of the $\mathrm{Cu}-\mathrm{XAl}-4 \mathrm{Ni}$ SMAs were performed using a Tescan 5136MM scanning electron microscope (SEM). The surface of each specimen was mechanically polished by sand papers followed by etching with a solution composed of $2.5 \mathrm{~g} \mathrm{FeCl}_{3} \cdot 6 \mathrm{H}_{2} \mathrm{O}$ and $10 \mathrm{ml}$ $\mathrm{HCl}$ in $48 \mathrm{ml}$ methanol for approximately $4 \mathrm{~min}$. The martensitic transformation behaviors of the $\mathrm{Cu}-\mathrm{XAl}-4 \mathrm{Ni}$ SMAs were determined using a TA Q10 differential scanning calorimeter (DSC) under a constant cooling/heating rate of 
Table 1 The chemical composition of the Ringer's solution.

\begin{tabular}{ll}
\hline \hline Constituent & $\mathrm{g} / \mathrm{l}$ \\
\hline $\mathrm{NaCl}$ & 8.6 \\
$\mathrm{KCl}$ & 0.3 \\
$\mathrm{CaCl}_{2} \cdot 2 \mathrm{H}_{2} \mathrm{O}$ & 0.33 \\
$\mathrm{H}_{2} \mathrm{O}$ & Balance \\
\hline
\end{tabular}

$10^{\circ} \mathrm{C} / \mathrm{min}$. The cathodic and anodic polarization Tafel curves of the $\mathrm{Cu}-\mathrm{XAl}-4 \mathrm{Ni}$ SMAs were analyzed using a Jiehan ECW-5600 electrochemical workstation, in which a platinum plate was used as the counter electrode, a saturated calomel electrode was used as the reference electrode, and Ringer's solution was used as the test solution, to calculate the average corrosion potential $\left(E_{\text {corr }}\right)$ and average corrosion current density $\left(i_{\text {corr }}\right)$ values of each specimen. The chemical composition of the Ringer's solution is listed in Table 1. The surface chemical compositions of the $\mathrm{Cu}-\mathrm{XAl}-4 \mathrm{Ni}$ SMAs were determined using Thermo Scientific (VGS) K-Alpha X-ray photoelectron spectroscopy (XPS) with a monochromatic Al K $\alpha$ radiation source of $1468.6 \mathrm{eV}$. The survey spectrum of each specimen was measured over a range of 0 to $1200 \mathrm{eV}$ in $1 \mathrm{eV}$ steps. High-resolution $\mathrm{Cu}, \mathrm{Al}$, and Ni $2 p$ spectra for each specimen were determined in $0.05 \mathrm{eV}$ steps. The selective leaching properties of the $\mathrm{Cu}-$ XAl-4Ni SMAs were evaluated by immersing the $\mathrm{Cu}-\mathrm{XAl}-$ $4 \mathrm{Ni}$ SMAs in test flasks containing $500 \mathrm{~mL}$ of Ringer's solution. Each test flask was maintained at $37^{\circ} \mathrm{C}$ in an orbital shaker incubator for 90 days. The concentrations of the $\mathrm{Cu}$, $\mathrm{Al}$, and $\mathrm{Ni}$ ions released from the $\mathrm{Cu}-\mathrm{XAl}-4 \mathrm{Ni}$ SMAs were determined using an Agilent 7500ce inductively coupled plasma mass spectrometer (ICP-MS).

\section{Results}

\subsection{XRD and SEM results}

Figure 1(a) presents the XRD results of the $\mathrm{Cu}-13.5 \mathrm{Al}-$ 4Ni SMA. Figure 1 (a) reveals that the $\mathrm{Cu}-13.5 \mathrm{Al}-4 \mathrm{Ni}$ SMA exhibited (110), (112), (022), (122), (202), (0018), (128), (208), and (1210) diffraction peaks of $\beta_{1}^{\prime}$ martensite phase at approximately $2 \theta=26.2^{\circ}, 26.8^{\circ}, 33.7^{\circ}, 39.6^{\circ}, 40.9^{\circ}$, $42.6^{\circ}, 44.4^{\circ}, 44.9^{\circ}$, and $45.8^{\circ}$, respectively. ${ }^{33)}$ According to Fig. 1(a), the $\mathrm{Cu}-13.5 \mathrm{Al}-4 \mathrm{Ni}$ SMA was typical $\beta_{1}^{\prime}$ martensite with an $18 \mathrm{R}$ structure at room temperature. The $\beta_{1}^{\prime}(18 \mathrm{R})$ martensite phase has an ordered $9 \mathrm{R}$ structure with stacking faults. The $\beta_{1}^{\prime}$ martensite phase is labeled as $18 \mathrm{R}$ because the unit cell of this structure in orthorhombic coordinates consist of 18 layers. Monoclinic distortion takes place in some cases and the 18R structure is slightly distorted from an orthorhombic cell to a monoclinic and modified as M18R. ${ }^{34)}$ Therefore, both three-index and four-index axes are used in Fig. 1(a). Figure 1(b) shows a SEM microstructure image of the $\mathrm{Cu}-13.5 \mathrm{Al}-4 \mathrm{Ni}$ SMA. As shown in Fig. 1(b), the surface of the $\mathrm{Cu}-13.5 \mathrm{Al}-4 \mathrm{Ni}$ SMA exhibited obvious selfaccommodating zigzag groups of martensite variants. This feature also demonstrates that the $\mathrm{Cu}-13.5 \mathrm{Al}-4 \mathrm{Ni}$ SMA

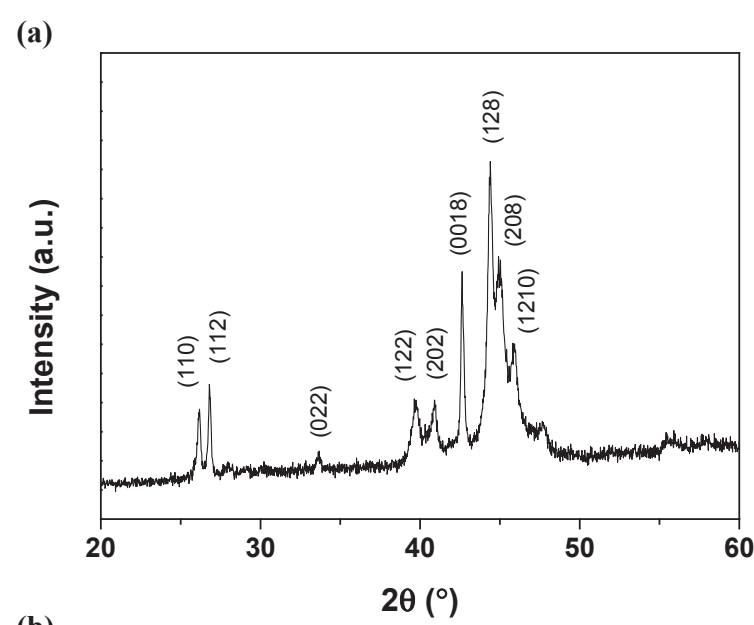

(b)

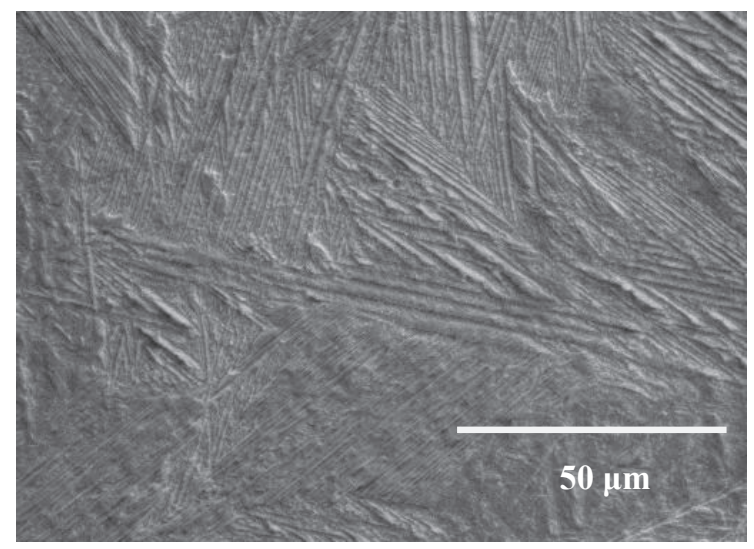

Fig. 1 (a) XRD pattern and (b) SEM image of the $\mathrm{Cu}-13.5 \mathrm{Al}-4 \mathrm{Ni}$ SMA.

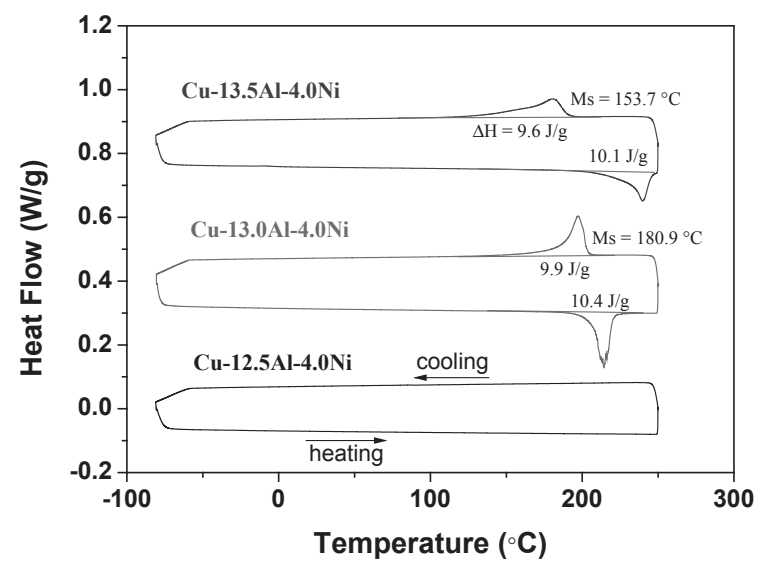

Fig. 2 DSC curves of the $\mathrm{Cu}-12.5 \mathrm{Al}-4 \mathrm{Ni}, \mathrm{Cu}-13.0 \mathrm{Al}-4 \mathrm{Ni}$, and $\mathrm{Cu}-$ 13.5Al-4Ni SMAs.

was in a $\beta_{1}^{\prime}(18 \mathrm{R})$ martensite phase at room temperature. ${ }^{24,29)}$ The XRD and SEM results of the $\mathrm{Cu}-13.0 \mathrm{Al}-4 \mathrm{Ni}$ and $\mathrm{Cu}-12.5 \mathrm{Al}-4 \mathrm{Ni}$ SMAs are not presented here, because they are very similar to those of the $\mathrm{Cu}-13.5 \mathrm{Al}-4 \mathrm{Ni}$ SMA.

\subsection{DSC results}

Figure 2 shows the DSC curves for the $\mathrm{Cu}-12.5 \mathrm{Al}-4 \mathrm{Ni}$, $\mathrm{Cu}-13.0 \mathrm{Al}-4 \mathrm{Ni}$, and $\mathrm{Cu}-13.5 \mathrm{Al}-4 \mathrm{Ni}$ SMAs. Figure 2 reveals that the $\mathrm{Cu}-13.0 \mathrm{Al}-4 \mathrm{Ni}$ and $\mathrm{Cu}-13.5 \mathrm{Al}-4 \mathrm{Ni}$ both exhibit $\beta_{1}\left(\mathrm{DO}_{3}\right) \rightarrow \beta_{1}^{\prime}(18 \mathrm{R})$ and $\quad \beta_{1}^{\prime}(18 \mathrm{R}) \rightarrow \beta_{1}\left(\mathrm{DO}_{3}\right)$ martensitic transformations in cooling and heating, 
respectively. The martensitic starting $(\mathrm{Ms})$ temperatures for the $\mathrm{Cu}-13.0 \mathrm{Al}-4 \mathrm{Ni}$ and $\mathrm{Cu}-13.5 \mathrm{Al}-4 \mathrm{Ni}$ SMAs were determined as $180.9^{\circ} \mathrm{C}$ and $153.7^{\circ} \mathrm{C}$, respectively. Figure 2 also shows that the transformation enthalpies $(\Delta \mathrm{H})$ for the $\mathrm{Cu}-13.0 \mathrm{Al}-4 \mathrm{Ni}$ and $\mathrm{Cu}-13.5 \mathrm{Al}-4 \mathrm{Ni}$ SMAs were both determined as approximately $10 \mathrm{~J} / \mathrm{g}$. However, the $\mathrm{Cu}-$ 12.5Al-4Ni SMA did not show any martensitic transformation peak in Fig. 2. This is because the martensitic transformation temperatures of the $\mathrm{Cu}-12.5 \mathrm{Al}-4 \mathrm{Ni}$ SMA was beyond the upper temperature limit of the DSC instrument $\left(250^{\circ} \mathrm{C}\right)$. According to the DSC results, we could ensure that the $\mathrm{Cu}-12.5 \mathrm{Al}-4 \mathrm{Ni}, \mathrm{Cu}-13.0 \mathrm{Al}-4 \mathrm{Ni}$, and $\mathrm{Cu}-13.5 \mathrm{Al}-4 \mathrm{Ni}$ SMAs were all in the same $\beta_{1}^{\prime}(18 \mathrm{R})$ martensite phase when they were subjected to the electrochemical, XPS, and selective leaching measurements.

\subsection{Electrochemical properties}

Figures 3(a) to 3(c) plot the cathodic and anodic polarization Tafel curves of the $\mathrm{Cu}-12.5 \mathrm{Al}-4 \mathrm{Ni}, \mathrm{Cu}-$ 13.0Al-4Ni, and $\mathrm{Cu}-13.5 \mathrm{Al}-4 \mathrm{Ni}$ SMAs, respectively. The potential was measured versus saturated calomel electrode (vs. SCE), in which the electrode potential of SCE is $+0.244 \mathrm{~V}$ vs. standard hydrogen electrode (SHE) at $25^{\circ} \mathrm{C}$. According to Tafel curves, the $E_{\text {corr }}$ values for the $\mathrm{Cu}-$ 12.5Al-4Ni, $\mathrm{Cu}-13.0 \mathrm{Al}-4 \mathrm{Ni}$, and $\mathrm{Cu}-13.5 \mathrm{Al}-4 \mathrm{Ni}$ SMAs were calculated as $-0.193 \pm 0.007,-0.205 \pm 0.006$, and $-0.204 \pm 0.004 \mathrm{~V}$, respectively. Moreover, the $i_{\text {corr }}$ values for the $\mathrm{Cu}-12.5 \mathrm{Al}-4 \mathrm{Ni}, \mathrm{Cu}-13.0 \mathrm{Al}-4 \mathrm{Ni}$, and $\mathrm{Cu}-13.5 \mathrm{Al}-$ $4 \mathrm{Ni}$ SMAs were calculated as $(9.31 \pm 0.489) \times 10^{-6}$, $(8.54 \pm 0.468) \times 10^{-6}$, and $(12.2 \pm 0.796) \times 10^{-6} \mathrm{~A} / \mathrm{cm}^{2}$, respectively. Compared with our previous studies, ${ }^{18,19)}$ the $E_{\text {corr }}$ values for the $\mathrm{Cu}-\mathrm{XAl}-4 \mathrm{Ni}$ SMAs (approximately $-0.2 \mathrm{~V})$ are slightly higher than those of the $\mathrm{Ti}_{50} \mathrm{Ni}_{50}$ (approximately $-0.496 \mathrm{~V}$ ), $\mathrm{Ti}_{50} \mathrm{Ni}_{50-\mathrm{x}} \mathrm{Cu}_{\mathrm{x}}$ (from -0.330 to $-0.416 \mathrm{~V}$ ), and $\mathrm{Ti}_{50} \mathrm{Ni}_{50-\mathrm{x}} \mathrm{Fe}_{\mathrm{x}}$ (from -0.379 to $-0.433 \mathrm{~V}$ ) SMAs. However, the $i_{\text {corr }}$ values for the $\mathrm{Cu}-\mathrm{XAl}-4 \mathrm{Ni}$ SMAs (approximately $10 \times 10^{-6} \mathrm{~A} / \mathrm{cm}^{2}$ ) are also higher than those of the $\mathrm{Ti}_{50} \mathrm{Ni}_{50}$ (approximately $7.57 \times 10^{-7} \mathrm{~A} / \mathrm{cm}^{2}$ ), $\mathrm{Ti}_{50} \mathrm{Ni}_{50-\mathrm{x}} \mathrm{Cu}_{\mathrm{x}}$ (from $2.43 \times 10^{-7}$ to $4.13 \times 10^{-7} \mathrm{~A} / \mathrm{cm}^{2}$ ), and $\mathrm{Ti}_{50} \mathrm{Ni}_{50-\mathrm{x}} \mathrm{Fe}_{\mathrm{x}}$ (from $3.27 \times 10^{-7}$ to $5.52 \times 10^{-6} \mathrm{~A} / \mathrm{cm}^{2}$ ) SMAs. This indicates that the corrosion rates of the $\mathrm{Cu}-\mathrm{XAl}-$ 4Ni SMAs in Ringer's solution are relatively higher than those of the TiNi-based SMAs. This feature may correspond to the fact that the $\mathrm{Cu}-\mathrm{XAl}-4 \mathrm{Ni}$ SMAs were in the $\beta_{1}^{\prime}(18 \mathrm{R})$ martensite phase, which exhibited a rough surface due to the surface relief phenomenon (Fig. 1(b)), when subjected to the electrochemical measurement. On the contrary, the $\mathrm{Ti}_{50} \mathrm{Ni}_{50}$, $\mathrm{Ti}_{50} \mathrm{Ni}_{50-\mathrm{x}} \mathrm{Cu}_{\mathrm{x}}$, and $\mathrm{Ti}_{50} \mathrm{Ni}_{50-\mathrm{x}} \mathrm{Fe}_{\mathrm{x}}$ SMAs were in the B2 parent phase with a smooth surface.

\subsection{X-ray photoelectron spectroscopy}

Figures 4(a) to 4(d) show the XPS survey, $\mathrm{Cu} 2 \mathrm{p}, \mathrm{Al} 2 \mathrm{p}$, and $\mathrm{Ni} 2 \mathrm{p}$ spectra, respectively, of the surfaces of the $\mathrm{Cu}-$ 13.5Al-4Ni SMA. Only the XPS results of the $\mathrm{Cu}-13.5 \mathrm{Al}-$ $4 \mathrm{Ni}$ SMA are shown here because those of the $\mathrm{Cu}-12.5 \mathrm{Al}-$ $4 \mathrm{Ni}$ and $\mathrm{Cu}-13.0 \mathrm{Al}-4 \mathrm{Ni}$ SMAs are almost identical to them. According to Fig. 4(a), the $\mathrm{Cu}-13.5 \mathrm{Al}-4 \mathrm{Ni}$ SMA showed significant characteristic peaks associated with $\mathrm{Cu}, \mathrm{Al}, \mathrm{O}$, and contamination $\mathrm{C}$ in the XPS survey spectrum. Figure $5(\mathrm{~b})$ shows that the $\mathrm{Cu} 2 \mathrm{p}$ characteristic peaks of the $\mathrm{Cu}-13.5 \mathrm{Al}-$ (a) Cu-12.5Al-4Ni SMA

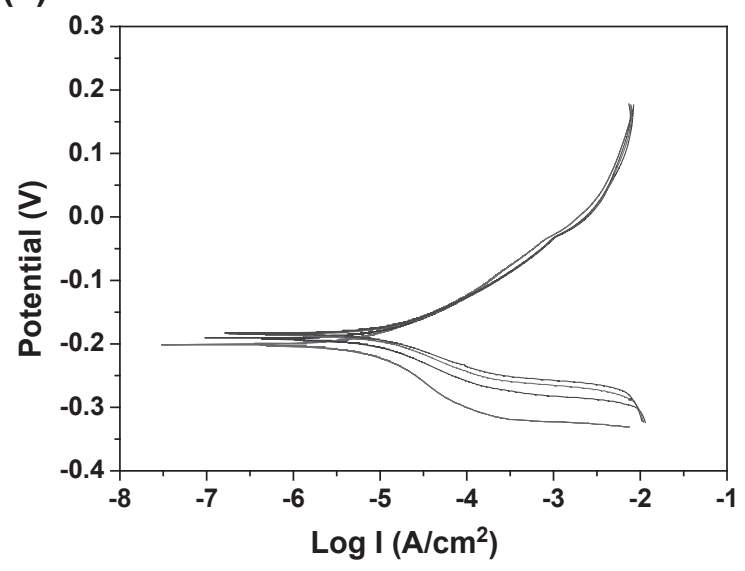

(b) Cu-13.0Al-4Ni SMA

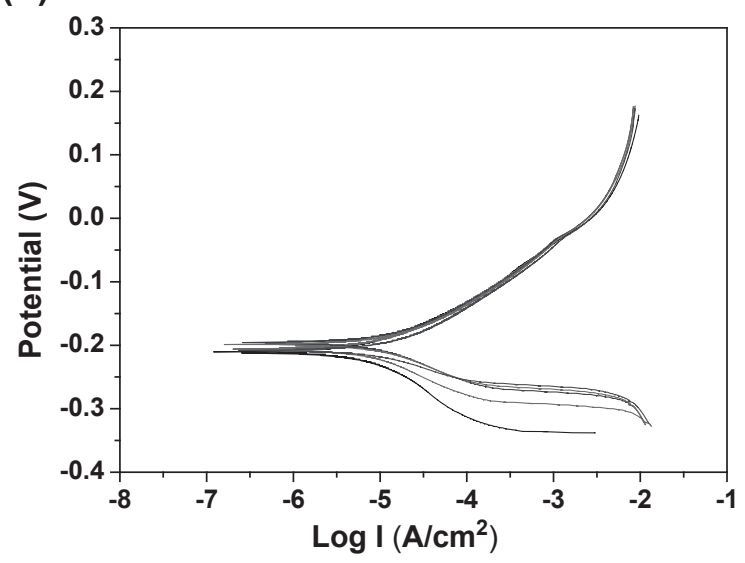

(c) $\mathrm{Cu}-13.5 \mathrm{Al}-4 \mathrm{Ni}$ SMA

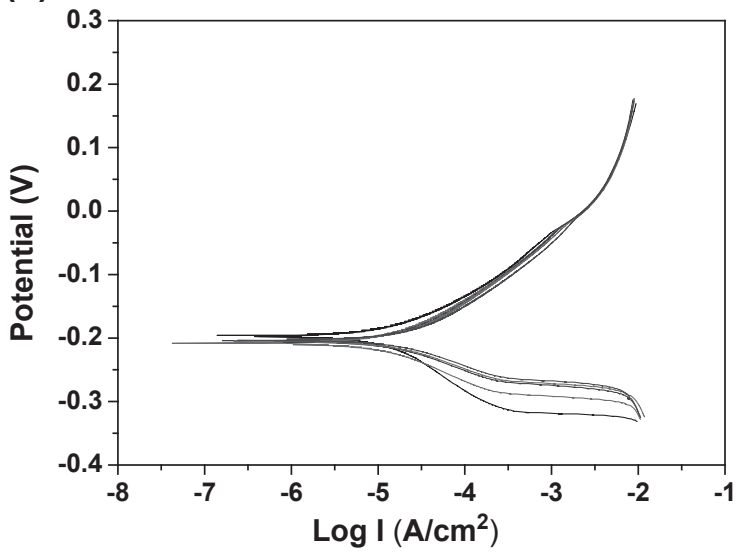

Fig. 3 Cathodic and anodic polarization Tafel curves for the (a) $\mathrm{Cu}-$ 12.5Al-4Ni, (b) $\mathrm{Cu}-13.0 \mathrm{Al}-4 \mathrm{Ni}$, and (c) $\mathrm{Cu}-13.5 \mathrm{Al}-4 \mathrm{Ni}$ SMAs.

4Ni SMA can be deconvoluted into a $\mathrm{Cu}_{2} \mathrm{O} 2 \mathrm{p} 3 / 2$ peak at $932.7 \mathrm{eV}$ and $\mathrm{a}_{2} \mathrm{O} 2 \mathrm{p} 1 / 2$ peak at $952.5 \mathrm{eV}$. Figure 5(c) shows that the $\mathrm{Al} 2 \mathrm{p}$ characteristic peaks of the $\mathrm{Cu}-13.5 \mathrm{Al}-$ $4 \mathrm{Ni}$ SMA can be deconvoluted into an $\mathrm{Al}_{2} \mathrm{O}_{3} 2 \mathrm{p} 3 / 2$ peak at $77.3 \mathrm{eV}$ and an $\mathrm{Al}_{2} \mathrm{O}_{3} 2 \mathrm{p}$ peak at $75.0 \mathrm{eV}$. Unexpectedly, as shown in Fig. 5(d), no Ni characteristic peak was obtained. According to Fig. 5, we can conclude that the surfaces of the $\mathrm{Cu}-13.5 \mathrm{Al}-4 \mathrm{Ni}$ SMA were dominantly composed of $\mathrm{Cu}_{2} \mathrm{O}$ and $\mathrm{Al}_{2} \mathrm{O}_{3}$ oxide layers. The $\mathrm{NiO}$ oxide layer, which was normally observed on the surface of TiNi-based SMAs, ${ }^{18,19)}$ was not observed on the surface of the $\mathrm{Cu}-\mathrm{XAl}-4 \mathrm{Ni}$ SMAs. 
(a) Cu-13.5Al-4Ni Survey

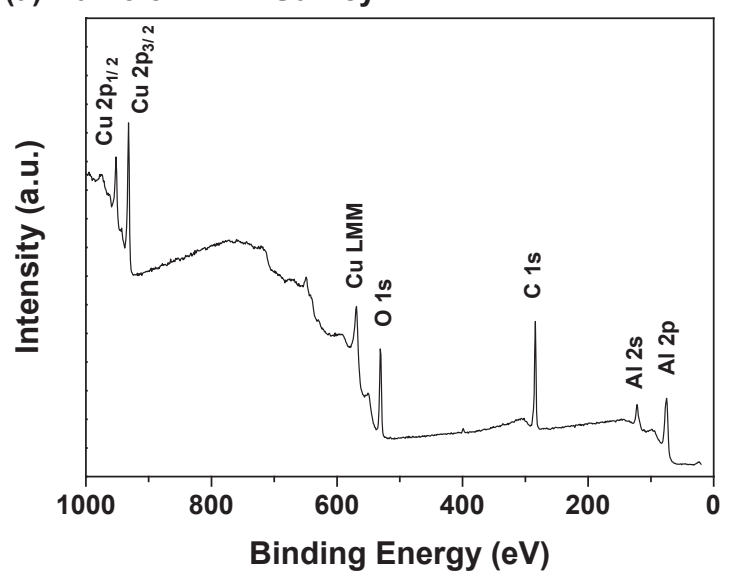

(c) Cu-13.5Al-4Ni Al 2p

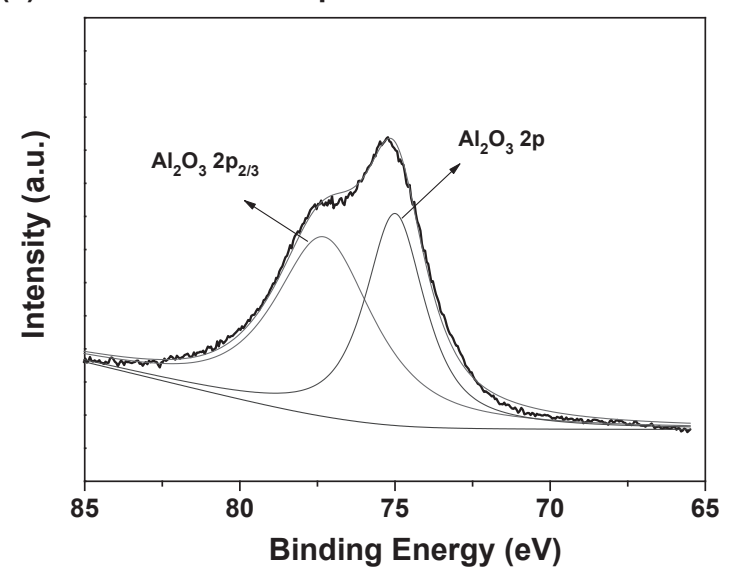

(b) $\mathrm{Cu}-13.5 \mathrm{Al}-4 \mathrm{Ni} \mathrm{Cu} 2 \mathrm{p}$

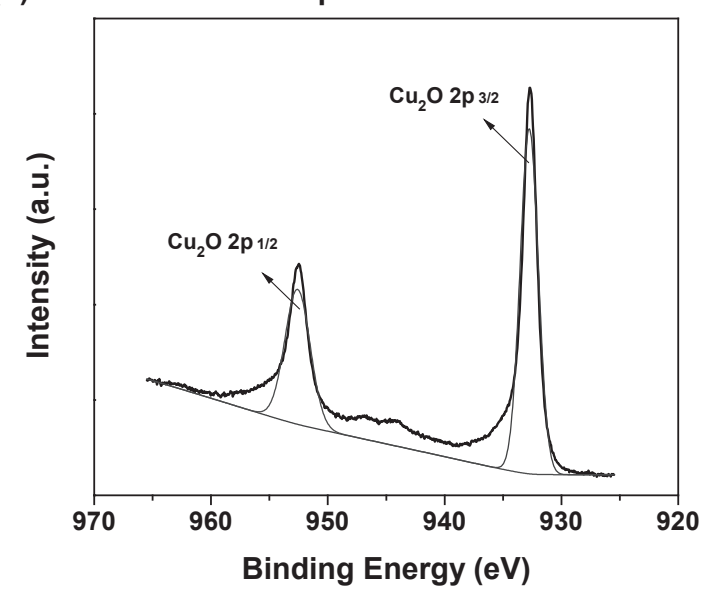

(d) $\mathrm{Cu}-13.5 \mathrm{Al}-4 \mathrm{Ni} \mathrm{Ni} 2 \mathrm{p}$

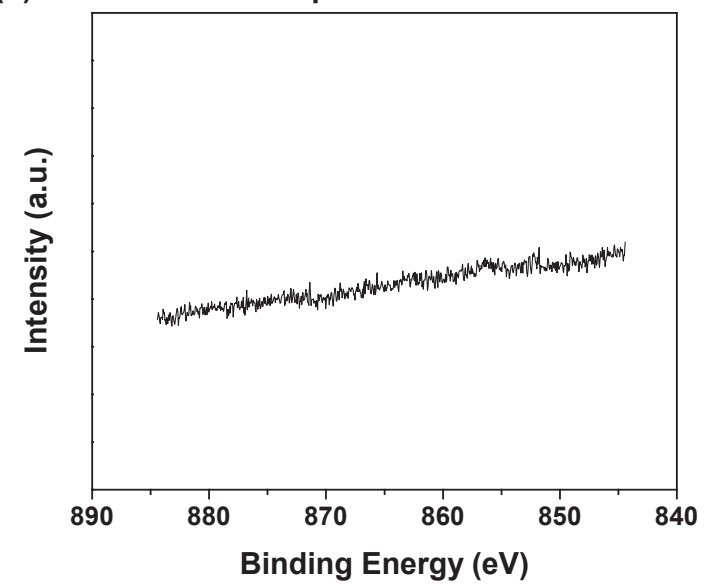

Fig. 4 XPS (a) survey spectrum, (b) Cu 2p spectrum, (c) Al 2p spectrum, and (d) Ni 2p spectrum of the surfaces of the Cu-13.5Al-4Ni SMA.

\subsection{Selective leaching behaviors}

Figures 5(a) to 5(c) show the concentrations of $\mathrm{Cu}, \mathrm{Al}$, and $\mathrm{Ni}$ ions, respectively, which were selectively leached from the $\mathrm{Cu}-\mathrm{XAl}-4 \mathrm{Ni}(\mathrm{X}=12.5,13.0$, and 13.5) SMAs immersed in Ringer's solution, as a function of immersion time. Figure 5(a) shows that the concentrations of $\mathrm{Cu}$ ions selectively leached from the specimens are approximately $200 \mathrm{ppb}$ after 90 days. The selective leaching behaviors of the $\mathrm{Cu}-\mathrm{XAl}-4 \mathrm{Ni} \mathrm{SMAs}$ do not show significant difference. Figure 5(b) shows that the concentrations of $\mathrm{Al}$ ions selectively leached from the specimens are below $200 \mathrm{ppb}$ after 90 days. Figure 5(c) shows that the concentrations of $\mathrm{Ni}$ ions selectively leached from the $\mathrm{Cu}-\mathrm{XAl}-4 \mathrm{Ni}$ SMAs gradually increased with the immersion time and approach greater than $600 \mathrm{ppb}$ after 90 days. As shown in Fig. 5, the selective leaching behaviors of the $\mathrm{Cu}, \mathrm{Al}$, and $\mathrm{Ni}$ ions for the $\mathrm{Cu}-12.5 \mathrm{Al}-4 \mathrm{Ni}, \mathrm{Cu}-13.0 \mathrm{Al}-4 \mathrm{Ni}$, and $\mathrm{Cu}-13.5 \mathrm{Al}-4 \mathrm{Ni}$ SMAs did not show significant differences. Moreover, Fig. 5 also reveals that the selective leaching rate of $\mathrm{Ni}$ ions from the $\mathrm{Cu}-\mathrm{XAl}-4 \mathrm{Ni}$ SMAs is much higher than those of $\mathrm{Cu}$ and $\mathrm{Al}$ ions, even though the weight percentage of $\mathrm{Ni}$ atoms is only approximately $4 \mathrm{wt} . \%$, which is much lower than those of $\mathrm{Cu}$ and $\mathrm{Al}$ atoms in the $\mathrm{Cu}-\mathrm{XAl}-4 \mathrm{Ni}$ SMAs. Compared with our previous studies, ${ }^{18,19)}$ the concentrations of the $\mathrm{Ni}$ ions selectively leached from the $\mathrm{Cu}-\mathrm{XAl}-4 \mathrm{Ni}$ SMAs (approximately $600 \mathrm{ppb}$ after 90 days) are much higher than that of the $\mathrm{Ti}_{50} \mathrm{Ni}_{50}$ SMA (approximately $25 \mathrm{ppb}$ after 30 days), but are much lower than those of the $\mathrm{Ti}_{50} \mathrm{Ni}_{50-\mathrm{x}} \mathrm{Cu}_{\mathrm{x}}$ (approximately $2500 \mathrm{ppb}$ after 30 days) and $\mathrm{Ti}_{50} \mathrm{Ni}_{50-\mathrm{x}} \mathrm{Fe}_{\mathrm{x}}$ (above $1500 \mathrm{ppb}$ after 80 days) SMAs. Moreover, the concentrations of the $\mathrm{Cu}$ ions selectively leached from the $\mathrm{Cu}-\mathrm{XAl}-4 \mathrm{Ni}$ SMAs (approximately $200 \mathrm{ppb}$ after 90 days) are also much lower than that of the $\mathrm{Ti}_{50} \mathrm{Ni}_{45} \mathrm{Cu}_{5}$ SMA (above $800 \mathrm{ppb}$ after 30 days), even though the weight percentage of $\mathrm{Cu}$ atoms is above $80 \%$ for the $\mathrm{Cu}-\mathrm{XAl}-4 \mathrm{Ni}$ SMAs.

\section{Discussion}

According to the selective leaching measurement results shown in Fig. 5, there are approximately $200 \mathrm{ppb}$ of $\mathrm{Cu}$ ions, $200 \mathrm{ppb}$ of $\mathrm{Al}$ ions, and $600 \mathrm{ppb}$ of $\mathrm{Ni}$ ions released from the $\mathrm{Cu}-\mathrm{XAl}-4 \mathrm{Ni}$ SMAs after immersion in Ringer's solution for 90 days. The concentrations of $\mathrm{Ni}$ ions after selective leaching from the $\mathrm{Cu}-\mathrm{XAl}-4 \mathrm{Ni}$ SMAs are much higher than those of $\mathrm{Cu}$ and $\mathrm{Al}$ ions, indicating that the $\mathrm{Ni}$ ions are more easily leached from the surface of the $\mathrm{Cu}-\mathrm{XAl}-4 \mathrm{Ni}$ SMAs than the $\mathrm{Cu}$ and $\mathrm{Al}$ ions, even though the weight percentage of Ni atoms was only $4 \mathrm{wt}$.\% for each specimen. This feature corresponds to the fact that the $\mathrm{Cu}$ and $\mathrm{Al}$ atoms near the surface were oxidized to become $\mathrm{Cu}_{2} \mathrm{O}$ and $\mathrm{Al}_{2} \mathrm{O}_{3}$ films on 


\section{(a) $\mathrm{Cu}$ ion}

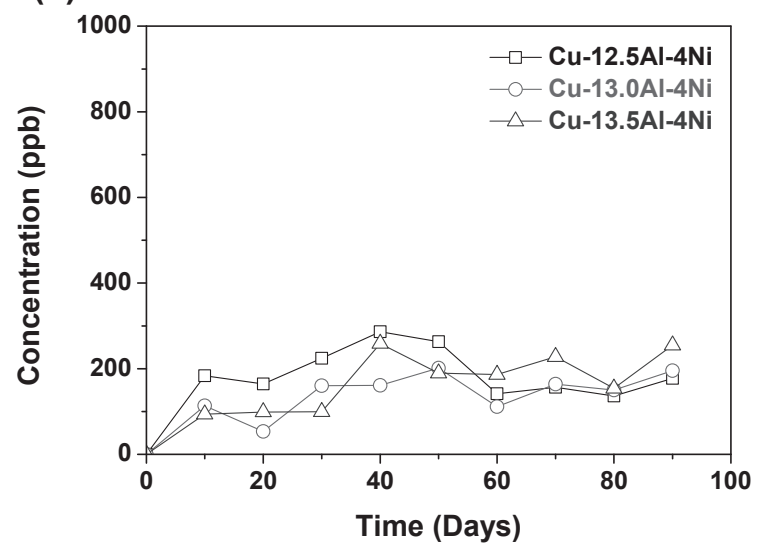

(b) Al ion

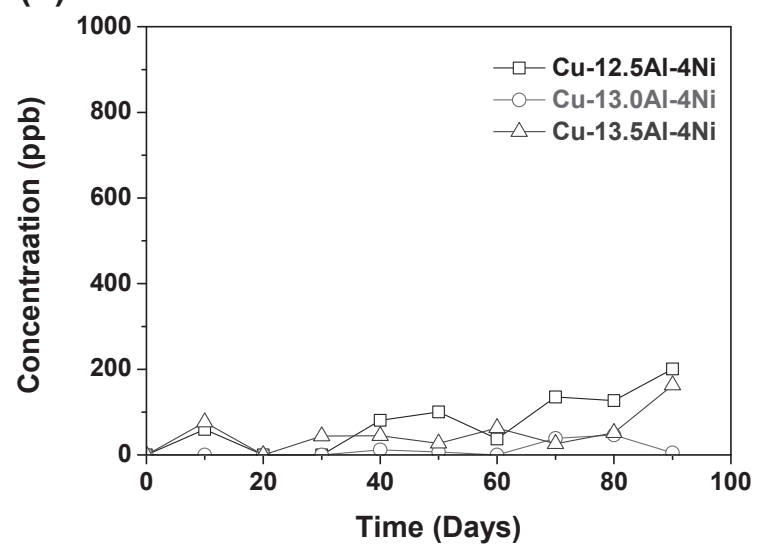

(c) $\mathrm{Ni}$ ion

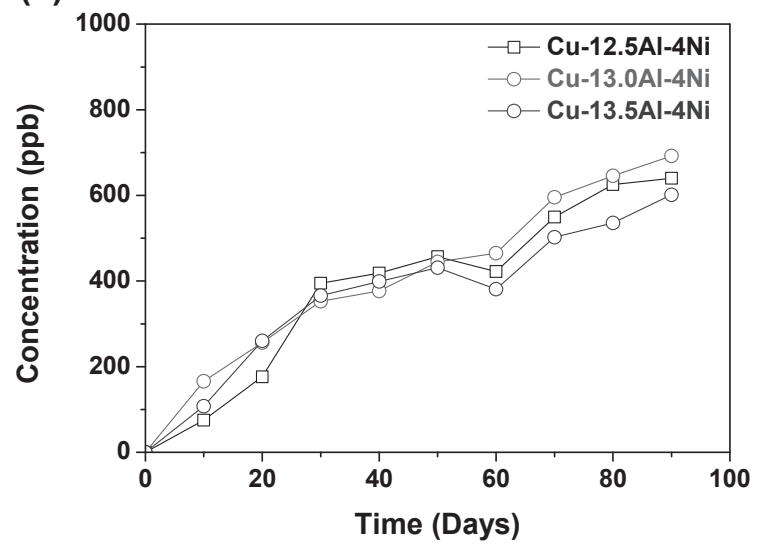

Fig. 5 Concentrations of the (a) $\mathrm{Cu}$, (b) $\mathrm{Al}$, and (c) Ni ions selectively leached from the $\mathrm{Cu}-12.5 \mathrm{Al}-4 \mathrm{Ni}, \mathrm{Cu}-13.0 \mathrm{Al}-4 \mathrm{Ni}$, and $\mathrm{Cu}-13.5 \mathrm{Al}-4 \mathrm{Ni}$ SMAs.

the surface of the $\mathrm{Cu}-\mathrm{XAl}-4 \mathrm{Ni}$ SMAs, as demonstrated by the XPS results shown in Fig. 5, which inhibited the selective leaching of the $\mathrm{Cu}$ and $\mathrm{Al}$ atoms.

Compared with the selective leaching results of the $\mathrm{Ti}_{50} \mathrm{Ni}_{50}$ SMA reported previously, ${ }^{18)}$ the concentrations of the released $\mathrm{Cu}, \mathrm{Al}$, and $\mathrm{Ni}$ ions from the $\mathrm{Cu}-\mathrm{XAl}-4 \mathrm{Ni}$ SMAs are much higher than those of the $\mathrm{Ti}$ and $\mathrm{Ni}$ ions released from the $\mathrm{Ti}_{50} \mathrm{Ni}_{50} \mathrm{SMA}$, which were both below $25 \mathrm{ppb}$ after 30 days. The extremely low concentrations of Ti and $\mathrm{Ni}$ ions selectively leached from the $\mathrm{Ti}_{50} \mathrm{Ni}_{50}$ SMAs is attributed to the good corrosion resistance and protection of the highly passive $\mathrm{TiO}_{2}$ film formed on the surface. However, the main shortcoming of the $\mathrm{Ti}_{50} \mathrm{Ni}_{50}$ SMAs is that their martensitic transformation temperatures are typically low and difficult to control, which severely limits their practical biomedical applications. Substituting $\mathrm{Cu}$ or $\mathrm{Fe}$ for $\mathrm{Ni}$ in the $\mathrm{Ti}_{50} \mathrm{Ni}_{50}$ SMA could effectively increase the martensitic transformation temperature and the mechanical properties of the $\mathrm{Ti}_{50} \mathrm{Ni}_{50}$ SMAs. Unfortunately, the concentrations of $\mathrm{Ni}$ ions selectively leached from the $\mathrm{Ti}_{50} \mathrm{Ni}_{50-\mathrm{x}} \mathrm{Cu}_{\mathrm{x}}$ SMAs (approximately $2500 \mathrm{ppb}$ after 30 days) and the $\mathrm{Ti}_{50} \mathrm{Ni}_{50-\mathrm{x}} \mathrm{Fe}_{\mathrm{x}}$ SMAs (above $1500 \mathrm{ppb}$ after 80 days) were simultaneously significantly increased. ${ }^{18,19)}$ This is because the uniformity and protection of the highly passive $\mathrm{TiO}_{2}$ films were deteriorated by the formation of $\mathrm{NiO}, \mathrm{Cu}_{2} \mathrm{O}$, and $\mathrm{Fe}_{2} \mathrm{O}_{3}$ oxides on the surface of the $\mathrm{Ti}_{50} \mathrm{Ni}_{50-\mathrm{x}} \mathrm{Cu}_{\mathrm{x}}$ and $\mathrm{Ti}_{50} \mathrm{Ni}_{50-\mathrm{x}} \mathrm{Fe}_{\mathrm{x}}$ SMAs.

From the results of this study, the selective leaching property of the $\mathrm{Cu}-\mathrm{XAl}-4 \mathrm{Ni}$ SMAs are not as good as that of the $\mathrm{Ti}_{50} \mathrm{Ni}_{50}$ SMA, but are still far superior to those of the $\mathrm{Ti}_{50} \mathrm{Ni}_{50-\mathrm{x}} \mathrm{Cu}_{\mathrm{x}}$ and $\mathrm{Ti}_{50} \mathrm{Ni}_{50-\mathrm{x}} \mathrm{Fe}_{\mathrm{x}}$ SMAs. Moreover, the $\mathrm{Cu}-$ XAl-4Ni SMAs also possess the advantages of low cost, good workability, exceptional electrical and thermal conductivities, and easily obtainable wide range of martensitic transformation temperatures by precise adjustment of the chemical compositions of the $\mathrm{Cu}-\mathrm{XAl}-4 \mathrm{Ni}$ SMAs. Owing to these benefits, the $\mathrm{Cu}-\mathrm{XAl}-4 \mathrm{Ni}$ SMAs are potential candidates for biomaterial applications. Nevertheless, considering the mediocre corrosion resistance of the $\mathrm{Cu}-$ XAl-4Ni SMAs, appropriate surface modifications would be required for them to be considered for use as longterm implants in human bodies. For example, surface modifications using bioactive coating materials, including hexamethyldisilazane, calcium phosphate, bioactive glass, chitosan, or some kinds of polymers which are also nontoxicity and exhibit good biocompatibility and antifungal activity.

\section{Conclusions}

This study investigated the selective leaching and surface properties of the $\mathrm{Cu}-\mathrm{XAl}-4 \mathrm{Ni}(\mathrm{X}=12.5,13.0$, and 13.5) SMAs. The SEM, XRD, and DSC results all demonstrated that the $\mathrm{Cu}-\mathrm{XAl}-4 \mathrm{Ni}$ SMAs were in a $\beta_{1}^{\prime}(18 \mathrm{R})$ martensite phase during the selective leaching tests. The electrochemical tests revealed that the $E_{\text {corr }}$ and $i_{\text {corr }}$ values for $\mathrm{Cu}-\mathrm{XAl}-4 \mathrm{Ni}$ SMAs are approximately $-0.2 \mathrm{~V}$ and $10 \times 10^{-6} \mathrm{~A} / \mathrm{cm}^{2}$, respectively. The XPS results showed that the surface of $\mathrm{Cu}-\mathrm{XAl}-4 \mathrm{Ni}$ SMAs was primarily comprised of $\mathrm{Cu}_{2} \mathrm{O}$ and $\mathrm{Al}_{2} \mathrm{O}_{3}$ films. The ICP-MS results indicated that the concentrations of $\mathrm{Ni}$ ions selectively leached from $\mathrm{Cu}-$ XAl-4Ni SMAs were higher than those of $\mathrm{Cu}$ and $\mathrm{Al}$ ions. The surface and selective leaching properties of the $\mathrm{Cu}-$ $\mathrm{XAl}-4 \mathrm{Ni}$ SMAs were inferior to those of the $\mathrm{Ti}_{50} \mathrm{Ni}_{50} \mathrm{SMA}$, but were much better than those of the $\mathrm{Ti}_{50} \mathrm{Ni}_{50-\mathrm{X}} \mathrm{Cu}_{\mathrm{x}}$ and $\mathrm{Ti}_{50} \mathrm{Ni}_{50-\mathrm{x}} \mathrm{Fe}_{\mathrm{x}}$ SMAs. The $\mathrm{Cu}-\mathrm{XAl}-4 \mathrm{Ni}$ SMAs remain potential candidates for biomedical applications because of their irreplaceable higher martensitic transformation temperatures, lower cost, higher electrical and thermal conductivities, and better machinability compared to the TiNi-based SMAs. 


\section{Acknowledgements}

The authors gratefully acknowledge the financial support provided by the Ministry of Science and Technology (MOST), Taiwan, under Grant No. MOST 104-2221-E197-004-MY3.

\section{REFERENCES}

1) K. Otsuka and X. Ren: Prog. Mater. Sci. 50 (2005) 511-678.

2) M. Assad, N. Lemieux, C.H. Rivard and L.H. Yahia: Biomed. Mater. Eng. 9 (1999) 1-12.

3) M. Es-Souni, M. Es-Souni and H. Fischer-Brandies: Anal. Bioanal. Chem. 381 (2005) 557-567.

4) M. Assad, A. Chernyshov, M.A. Leroux and C.H. Rivard: Biomed. Mater. Eng. 12 (2002) 225-237.

5) P. Filip, J. Lausmaa, J. Musialek and K. Mazanec: Biomaterials 22 (2001) 2131-2138.

6) Y. Oshida, R.C.L. Sachdeva and S. Miyazaki: Biomed. Mater. Eng. 2 (1992) 51-69.

7) J.Y. Xiong, Y.C. Li, X.J. Wang, P.D. Hodgson and C.E. Wen: J. Mech. Behav. Biomed. Mater. 1 (2008) 269-273.

8) S.A. Shabalovskaya: Biomed. Mater. Eng. 6 (1996) 267-289.

9) F.El. Feninat, G. Laroche, M. Fiset and D. Mantovani: Adv. Eng. Mater. 4 (2002) 91-104.

10) H. Takahashi, M. Kinbara, N. Sato, K. Sasaki, S. Sugawara and Y. Endo: Int. Immunopharmacol. 11 (2011) 1534-1540.

11) V. D'Antò, A. Eckhardt, K.A. Hiller, G. Spagnuolo, R. Valletta, L. Ambrosio, G. Schmalz and H. Schweikl: Biomaterials 30 (2009) 1492 1501 .

12) C.L. Chu, C.Y. Chung and P.K. Chu: Mater. Sci. Eng. A 417 (2006) 104-109.
13) R.M. Wang, C.L. Chu, T. Hu, Y.S. Dong, C. Guo, X.B. Sheng, P.H. Lin, C.Y. Chung and P.K. Chu: Appl. Surf. Sci. 253 (2007) 8507-8512.

14) C.L. Chu, C. Guo, X.B. Sheng, Y.S. Dong, P.H. Lin, K.W.K. Yeung and P.K. Chu: Acta Biomater. 5 (2009) 2238-2245.

15) E. Espinar, J.M. Llamas, A. Michiardi, M.P. Ginebra and F.J. Gil: J. Mater. Sci. Mater. Med. 22 (2011) 1119-1125.

16) C. Abalos, A. Paúl, A. Endoza, E. Solano and F.J. Gil: J. Mater. Sci. Mater. Med. 22 (2011) 2813-2821.

17) F.J. Gil, E. Espinar, J.M. Llamas, J.M. Manero and M.P. Ginebra: J. Mech. Behav. Biomed. Mater. 6 (2012) 113-119.

18) S.H. Chang and W.C. Chiu: Appl. Surf. Sci. 324 (2015) 106-113.

19) S.H. Chang, J.S. Liou and B.Y. Huang: Mater. Tehnol. 51 (2017) 251257.

20) H. Scherngell and A.C. Kneissl: Acta Mater. 50 (2002) 327-341.

21) S.H. Chang: Mater. Lett. 64 (2010) 93-95.

22) G. Lojen, M. Gojić and I. Anžel: J. Alloys Compd. 580 (2013) 497-505.

23) N. Suresh and U. Ramamurty: J. Alloys Compd. 449 (2008) 113-118.

24) S.H. Chang: Mater. Chem. Phys. 125 (2011) 358-363.

25) H. Kato, R. Stalmans and J. Van Humbeeck: Mater. Trans. 39 (1998) 378-386.

26) C. Picornell, J. Pons and E. Cesari: Mater. Trans. 45 (2004) 1679-1683.

27) Y. Nakata, Y. Iizuka and T. Ono: Mater. Trans. 57 (2016) 257-262.

28) M. Čolić, R. Rudolf, D. Stamenković, I. Anžel, D. Vučević, M. Jenko, V. Lazić and G. Lojen: Acta Biomater. 6 (2010) 308-317.

29) M. Čolić, S. Tomić, R. Rudolf, I. Anžel and G. Lojen: J. Biomater. Appl. 25 (2010) 269-286.

30) R. Rudolf, K. Mehrabi, A.C. Kneissl, M. Bruncko, I. Anžel, S. Tomić, T. Džopalic and M. Čolić: Int. J. Immunol. Stud. 1 (2010) 214-228.

31) S.H. Chang, B.Y. Chen and J.X. Lin: J. Appl. Biomater. Funct. Mater. 14 (2016) e59-e64.

32) N. Zárubová, A. Gemperle and V. Novak: Mater. Sci. Eng. A 222 (1997) 166-174.

33) R. Zengin and M. Ceylan: Mater. Lett. 58 (2004) 55-59.

34) U. Sarı and İ. Aksoy: J. Alloys Compd. 417 (2006) 138-142. 